\title{
PESTS OF LEAFY VEGETABLES IN SRI LANKA, THEIR DAMAGED SYMPTOMS, HOST RANGE AND BIOLOGY
}

\author{
Sujeewa Kumari L.G. ${ }^{1 *}$, Bandara K.M.C.P. ${ }^{2}$, Bandara K.A.N.P. ${ }^{3}$ and Nishantha K.M.D.W.P. ${ }^{3}$ \\ ${ }^{1}$ Agro Technology Park, Gannoruwa, Department of Agriculture, \\ ${ }^{2}$ Faculty of Agriculture, University of Peradeniya, \\ ${ }^{3}$ Horticulture Crop Research and Development Institute, Peradeniya \\ *Corresponding Author: sujeewaagri@gmail.com ( (iD) https://orcid.org/0000-0002-9009-1609) \\ Received: 22.10.2021; Accepted: 04.01.2022 ; Published: 31.01 .2022
}

\begin{abstract}
Detail investigations on pests of leafy vegetables of Sri Lanka were carried out using three representative districts to generate background information required for development of sustainable management technologies. The methods included field sampling, laboratory culturing, and biological studies. Host range and biology of already recorded major pests, flea sap sucking bug, Halticus minitus (Heteroptera: Miridae) and flea beetle Chaetocnema spp. (Coleoptera: Chrysomelidae) under local conditions were described in detail. A new flea weevil pest damaging to Alternanthera sessilislinn linn. was identified as Tachyerges spp. (Coleoptera: Curculinoidae) and its morphology, biology and damage were described. In addition, a new flea beetle, Chaetocnema confinis was identified as a major pest of Ipomoea aqutica. Two leaf folder pests, Psara basalis (Lepidoptera: Crambidae) and beet webworm, Spoladeare recurvalis (Lepidoptera; Pyralidae) in A. sessilis and Amaranthus spp. respectively and a Bracon larval parasitoid of S. recurvalis were identified. Thrips, nematode, mites and plant bug were the other general pests damage to leafy vegetables including Centella asiatica.
\end{abstract}

Keywords: Biology, Damage, hosts, Leafy vegetables Pests, Sri Lanka

\section{INTRODUCTION}

Leafy vegetables are one of the essential components in the Sri Lankan diet and the most popular varieties such as Gotukola (Centella asiatica), Mukunuwenna (Alternanthera sesilis linn), Kangkun (Ipomoea aqutica), Thampala (Amaranthus candatus), Nivithi (Spinacia oleracea) and Kathurumurunga (Sesbania grandiflora) have been commercially cultivated. Intensifying pest problems due to environmental changes and continued commercial cultivations become the major constraint for their production and quality maintenance and compelled farmers to use insecticides creating health and environmental hazards (Lakshani et al., 2018). Therefore, sustainable management technologies were required to mitigate the situation and safeguard the farmers. Sound knowledge of the pest fauna of leafy vegetables is required to develop such management technologies. As the information provided by previous studies (Wijerathne, 1999; Wahundeniya et al., 2005; Marasingha and Nishantha, 2018; Rajshkanna et al., 2017) was not sufficient to meet these requirements, detailed investigation of the pests of leafy vegetables of Sri Lanka, their damage symptoms, host ranges and biology were investigated.

\section{METHODOLOGY}

Leafy vegetable cultivations in three representative commercial leafy vegetable cultivating districts, Gampaha (Dompe), Chillaw (Bingiriya), and Kandy (Peradeniya) were surveyed during the period of 2017 to 2020 in this study. The cultivations in the surroundings of Peradeniya were examined in fortnight intervals, whereas in the rest of the areas it was done periodically. The samples were collected by handpicking and using a sweep net and crop damages were visually estimated using $0-4$ scale $(0=$ no damaged; $1=$ up to $10 \%$ top three leaves have the damaged; $2=$ up to $11-25 \%$ of top three leaves have damaged; $3=26-50 \%$ of top three leaves have damaged; above $50 \%$ of top three leaves have damaged). The collected samples of suspected pests were separately reared on respective hosts in insect-proof containers / cages in the laboratories of Entomology division, Horticulture Crop Research and Development Institute (HORDI), Gannoruwa, Peradeniya for their identification and biological studies. Morphological identification of pests was done using stereo microscopic observation and then comparing their morphological characteristics of recorded pests. However, identification keys Hackston (2020) were used for identification of the new flea weevil pest. Host preference studies were carried out under choice conditions offering them detached twigs or whole plants of different leafy 
vegetables together in a watered plastic cup kept in insect-proof cages having the respective pest. The life cycle studies and host preference studies were carried out in three replications under the prevailing environmental conditions in the laboratory $\quad\left(26-32^{\circ} \mathrm{C} ; \quad 66-88 \quad \mathrm{RH} ;\right.$ natural illumination) and averages of 10 observations were made when taking quantitative measurements.

\section{RESULTS AND DISCUSSION}

1. Flea sap sucking bug, Halticus minitus (Heteroptera: Miridae)
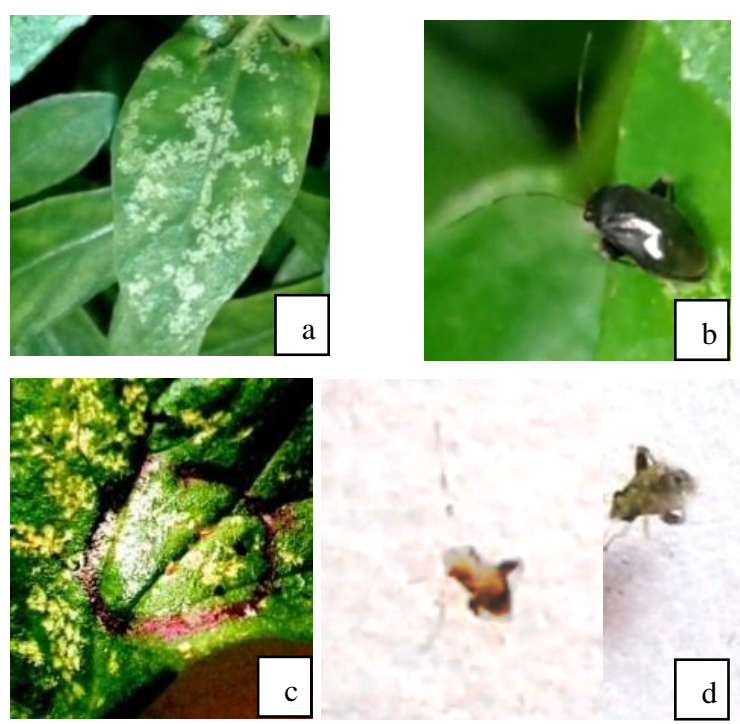

Plate1: Life cycle and damage of flea sap sucking bugs, Halticus minitus, a-damaged symptom of Mukunuwenna b-adult c-eggs, d- nymphs

Damage: This was a reported pest of Gotukola and Mukunuwanne in Sri Lanka (Wijerathne, 1999: Wahundeniya et al. 2005). The present study revealed that in addition to these two hosts, the pest damage to a number of other vegetables and some weeds, including Kangkun as a preferred host (Table 1). Damaged observations indicated that this pest was a frequently observed major pest of gotukola and mukunuwenna, which optimize its leaf damage exceeding $75 \%$ during dry periods in some locations. Both adults and nymphs suck the sap from the leaf tissues producing white stippling or irregular-shaped marks (speckled) on the leaf surface (Plate 1 a). In severe infestations, the leaves become grayish-white or silver color patches. The quality of leafy vegetables gets completely deteriorated due to their feeding, ovipostion and depositing of excreta on the leaves. The excreta were appeared as black spots on the leaves. Halticus spp. has been recorded as a widely spread pest of many crops and weeds in the Asia Pacific region (Amalin and Vasquez, 1993; Eyles, 2005).

Biology: The shiny black adults have grayish black posterior wing and about $2 \mathrm{~mm}$ long body (Plate 1 b). It has 4 segmented long and slender antennae and the first segment was thick and shorter than the rest, and the fourth segment was dark brown. The well-developed hind femora help them to jump when disturbed. Apical parts of legs were black and rests of the parts were brownish yellow. Eggs were inserted in to the leaves and stems of the plants on which the females feed (Plate $1 \mathrm{c}$ ). The whitish, translucent eggs about $0.4 \pm-0.1 \mathrm{~mm}$ in length become red mixed creamy appearance towards maturity and it takes 10-12 days to hatch. It has been distributed in the countries of pacific region and reported that the early nymphs were green in color (Tsatsia and Jackson 1999). However, in the present study they were observed in red mix creamy in color with dark red eyes. Antennae of nymphs were creamy yellow in color with two red spots (Plate $1 \mathrm{~d}$ ). Towards maturity, the nymphs turn to grayish green and finally emerge as shiny black adults. The whole life cycle takes about 3-4 weeks under laboratory conditions.

\section{Flea beetle, Chaetocnema spp. (Coleoptera: Chrysomelidae)}

Flea beetle, Chaetocnema spp. has already been reported as a major pest of Mukunuwenna (Wahundeniya et al., 2005; Marasinghe and Nishantha, 2018). The present investigation revealed that in addition to Mukunuwenna, this pest could make economic damage to a number of leafy vegetables (Table 1). The adult chew both sides of leaves making small round holes (shotholes) but some damaged spots appears as windows due to the presence of the epidermis (Plate 2 a). The shiny black adult about $2.2 \pm 0.2$ $\mathrm{mm}$ in length had light brown, eleven segmented antennae which gets darker color towards the end (Plate 2 b). Elliptical shape eggs in white color about $0.5 \mathrm{~mm}$ were laid in the soil around the base of the host plant and they get hatched within 6-7 days under laboratory conditions (Plate $2 \mathrm{c}$ ). The white color young larvae about $1 \mathrm{~mm}$ in length grow up to $3 \mathrm{~mm}$ in length and head turn to black toward maturity (Plate $2 \mathrm{~d}$ ). Afterwards, the larvae pupate in the soil and become adults after 7-10 days.

\section{Flea weevil, Tachyerges spp. (Coleoptera: Curculinoidae)}

Damage: A new flea weevil pest causing leaf damage to Mukunuwenna was identified as, Tachyyerges spp. (Coleoptera: Curculinoidae) (Hackston, 2020). The adult makes leaf holes similar to the damage caused by flea beetle and therefore could not be differentiated by damaged symptoms (Plate 3 a). Laboratory feeding studies indicated that it could cause damage to a range of other leafy vegetable crops (Table 1). The adult prefers younger leaves for feeding and damage appears as small windows and holes in the leaves. Larvae make mine in mature leaves but not prominent as adult damage (Plate 3 b. Both flea 
beetle and flea weevil damages were observed in some instances in the same field and seriously affected the quality of the harvest. The present investigations reveals that this pest as an occasional pest of leafy vegetables present in all three districts. However, the pest caused very high leaf damage to mukunuwenna in Gannourwa area in July-August, 2017.

Morphology \& Biology: The adult is about 2.0 $\pm 0.2 \mathrm{~mm}$ in length and reddish brown with paler irregular markings on the elytra (Plate $4 \mathrm{c}$ ). Thorax was darker than the rest of the body. Rostrum, legs and the body were hairy (Plate $4 \mathrm{~d}$ ). Eyes were black and large. Body shape is broad and convex. Abdomen consists five segments. The antennae
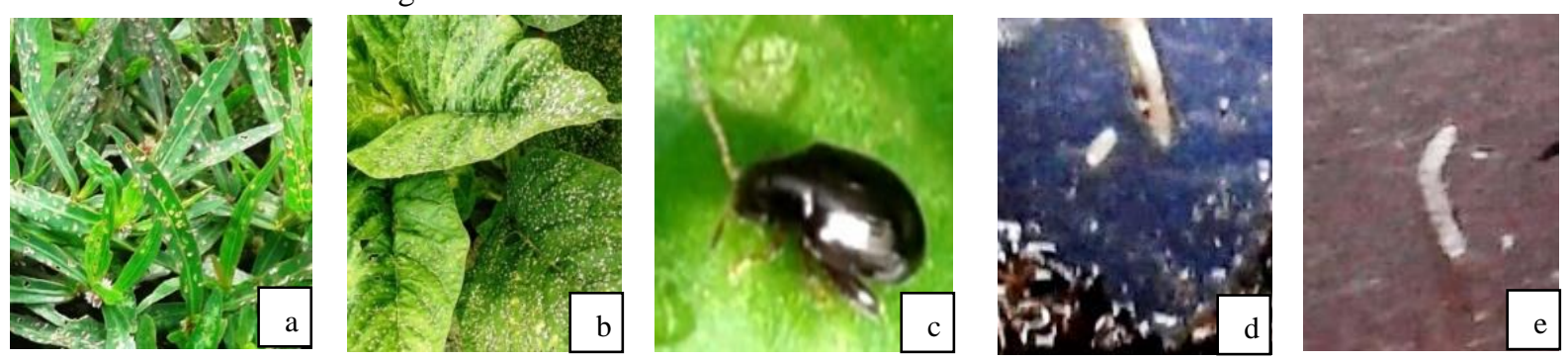

Plate 2: Life cycle and damage of Flea beetles, Chaetocnema spp, a-damaged in Mukunuwenne and Thampala b-enlarged adult, c-enlarged egg, d-enlarged larvae
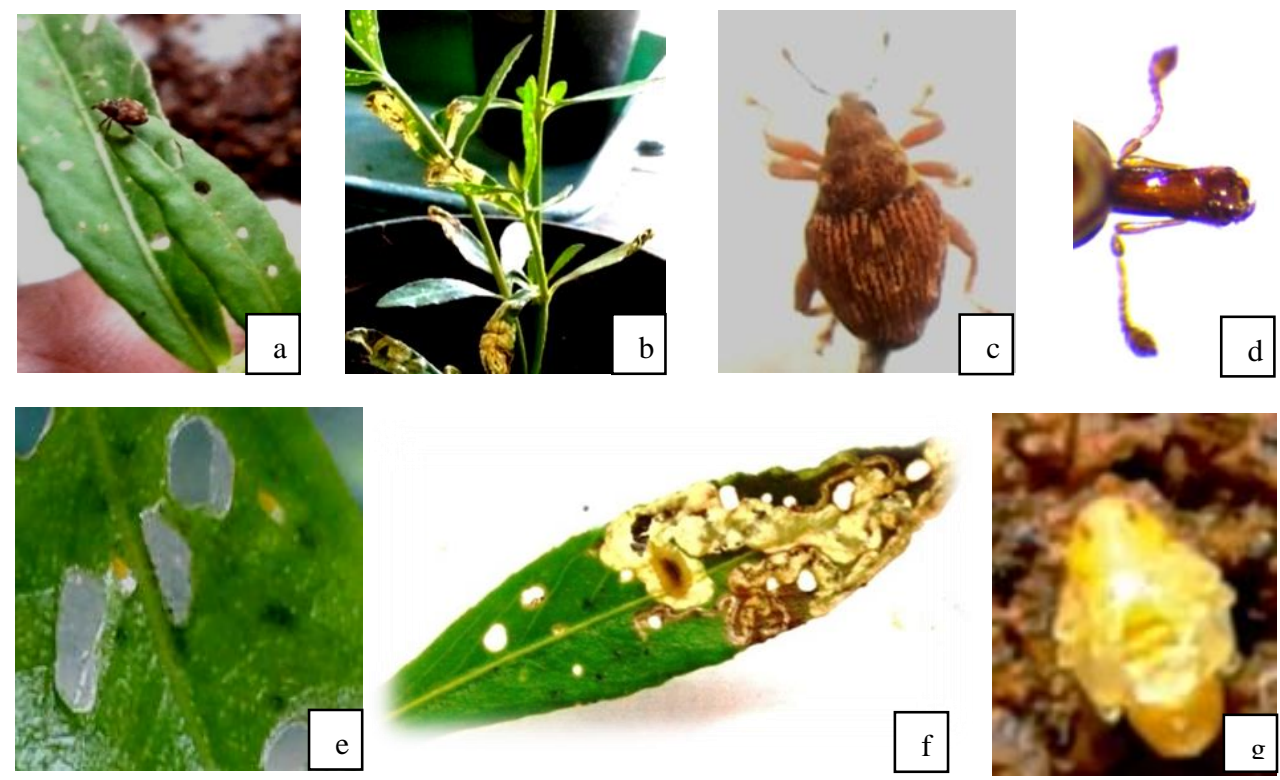

Plate 3: Life cycle and damage of flea weevil, Tachyyerges spp, enlarged a-adult damage, b-larvae damage c-adult, drostrum, e-eggs f- larvae in a tunnel, g-pupa

\section{Sweet potato flea beetle, Chaetocnema confinis Crotch (Coleoptera: Chrysomelidae)}

A new flea beetle species causing new type of damage to Kankun was observed and its damage reached to $100 \%$ in Gannoruwa area during January-February 2018. It appeared as whitish streaks on leaves and they turned to yellow and brownish later completely destroyed the crop. These damage symptoms were completely different from the already recorded flea beetle to
Mukunuwenna (Plate 4 a \& b). However, it was found that this damage similar to the damage caused by sweet potato flea beetle, Chaetocnema confinis to Kankun and Sweet potato Tsatsia and Jackson (2019). Further morphological studies indicated that both species have similar appearance but the new species was smaller $(1.4 \pm 0.2 \mathrm{~mm})$ than the already recorded flea beetle of Mukunuwenna (2.3-2.5 mm) and feeding studies indicated that it caused no damage to 
Mukunuwenna. The adult beetle is black to dark bronze and striae on the elytra were parallel and the Punctures are deep on the pronotum and similar to sweet potato flea beetle, C. confinis (Jolivet, 2008; Ruan et al., 2019) (Plate 4 c). These findings confirm that this new species is the invasive flea beetle species, $C$. confinis, which has not been recorded earlier in Sri Lanka (Ruan et.al., 2019).

\section{Leaf webber, Psara basalis (Lepidoptera: Crambidae)}

Leaf webber damage was recorded in the all three districts which caused around 5\% damage to mukunuwenna as its preferred host. This is a recorded leaf Webber species in Celosia spp. in Sri Lanka and the present study identified it as a pest of Mukunuwenna and Amaranthus spp. (Wijerathne, 1999). Yellowish green larvae with dark brown heads grew up to $1 \mathrm{~cm}$ in length, having two dark spots on the thorax with green stripes running along the body (Plate 5 a) (James $e t$ al. 2010).

The young caterpillars fold Tampala and Mukunuwenna leaves into shelters and feed and live inside them (Figure 5 b). Morphological characteristics confirm this leaf Webber pest as Psara basalis Walker (Lephidopters: Crambidae) (Kumar et al., 2008) (Figure 5 c).
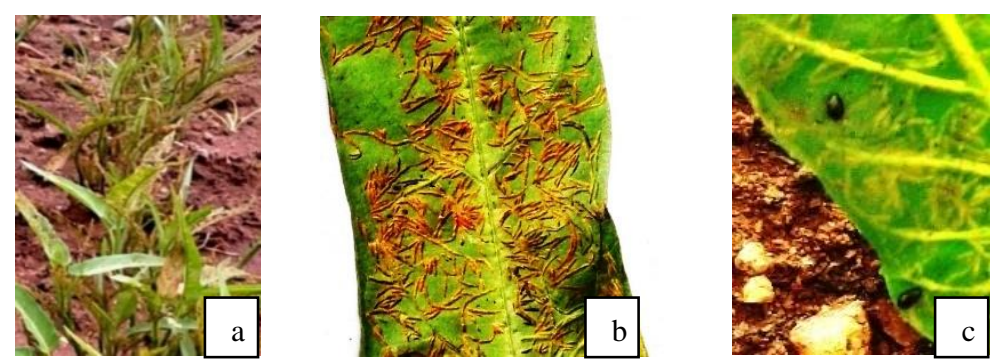

Plate 4: Sweet potato beetle, Chaetocnema confinis damage to kankun. a. damaged crop b. enlarged damaged leaf, c. the adult
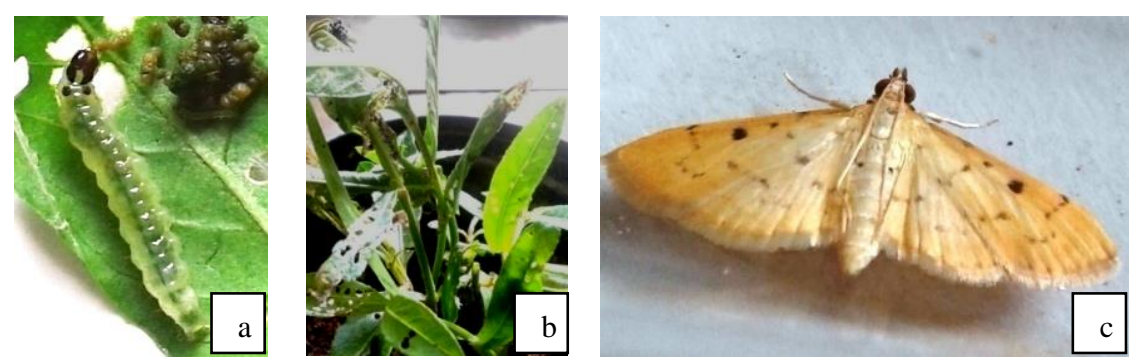

Plate 5: Psara basalis a-larva, b. damage, c. adult moth
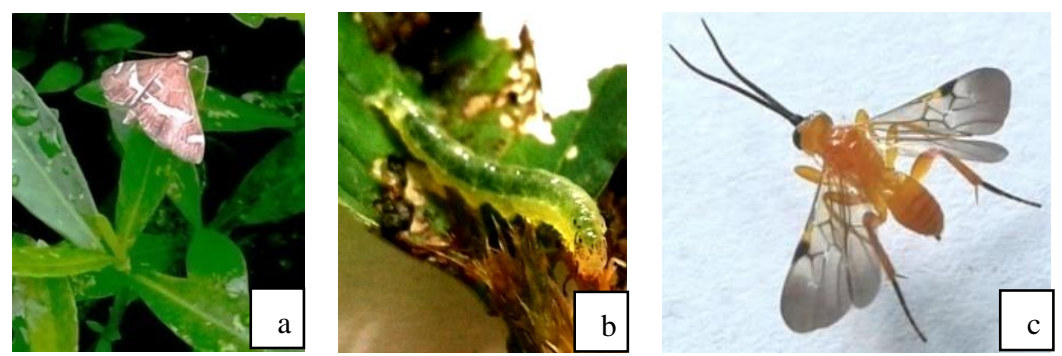

Published by University of Colombo Institute for Agro-Technology and Rural Sciences 
Plate 6: a. Beet webworm, Spoladea recurvalis a. adult b. larvae, c. Adult of Bracon parasitoid of Spoladea recurvalis

Table 1: Hosts of Halticus minitus, Chaetocnema spp. and Tachyyerges spp. identified in the study

\begin{tabular}{ccc}
\hline Pests & Common name & Scientific name \\
\hline Halticus minitus, & Mukunuwenna & Alternanthera sessilis linn. \\
Flea sap sucking bugs & Gotukola & Centella asiatica \\
(Heteroptera: Miridae) & Kankung & Ipomoea aqutica \\
& Wing bean & Psophocarpus tatragonolobus \\
& Elabatu & Solanum insamum \\
& Centrosema wel & Centrosem apubescens \\
& Wathupalu & Mikania cordata \\
Chaetocnema spp. & Sweet potato & Ipomoea batatas \\
Flea beetle & Long bean & Vigna unguiculate \\
(Coleoptera: Chrysomelidae) & Brinjal & Solanum melongena \\
\hline Tachyyerges spp., Flea weevil & Mukunuwenna & Alternanthera sessilislinn \\
(Coleoptera: Curculinoidae) & Thampala & Amaranthus candatus \\
& Nivithi & Spinacia oleracea \\
& Mal mukunuwenna & Alternanthera bettzickiana \\
& Katukoora & Amaranthus spinosus \\
& KooraThampala & Alternanthera viridis \\
\hline
\end{tabular}

\section{Thrips}

Thrips caused a considerable damage to Kankun crop, which appears as scraping mainly on underside of the leaves resulted curling, and deformation of leaves. In some instance, silvery appearance of veins on the upper side of the leaves was also observed (Plate 7 a \& b). The species could not be identified.

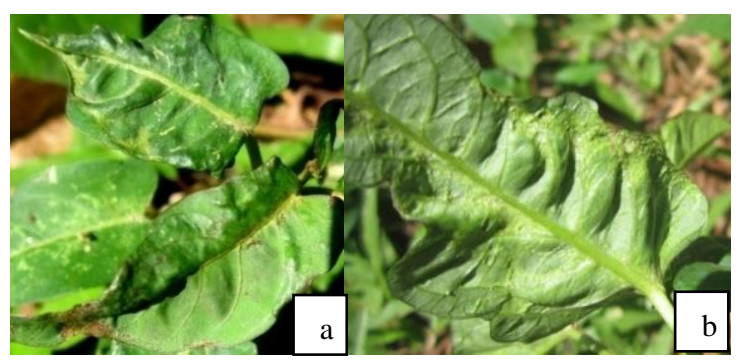

Plate 7:The leaf damage caused by thrips to kankun. a damaged plant $b$. enlarged leaf

\section{Coreid bug, Cletus trigonus Thunb}
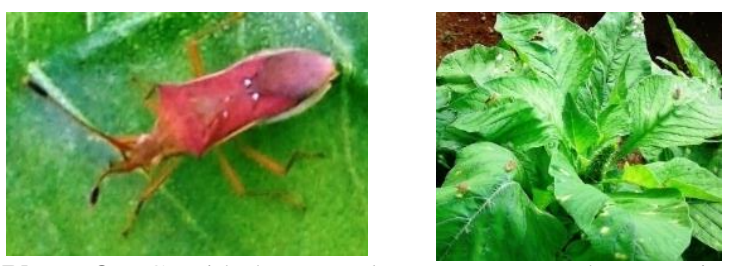

Plate 8: Coreid bugs, Cletus trigonus damage in thampala
Coreid bug, Cletus spp. is recorded as a pest of Amaranthus spp in Sri Lanka (Wijerathne, 1999). The present study identified the pest damage to Amaranthus spp. as C. trigonus (Heteroptera: Coredae) (Kafle and Lamjung, 2018; Gupta and Sing, 2013). (Plate 8).

\section{Mite pests}

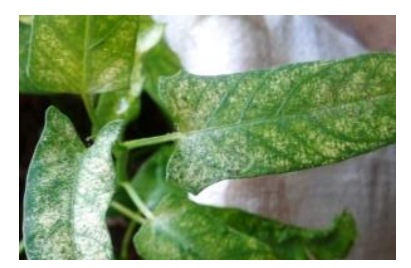

Plate 9: Red spider mite, Tetranychus urticae (Acari:Tetranychidae) damage in Kankun

Mites were another group of pests, which attacked leafy vegetables. The damage of red spider mite, Tetranychus urticae (Acari: Tetranychidae) was found as a common pest of a number of leafy vegetables such as Gotukola, Mukunuwenna, Thampala, Kathurumurunga, and Kankun and their damage was observed as a pale color stippling on leaves (Plate 9) (Zhang 2003). This mite was previously reported as a pest of Gotukola (Wahundeniya et al. 2005). In addition, the damage of broad mite, Polyhagotarsonemus latus (Banks) (Acari: Tarsonemidae) was observed as a minor pest in Mukunuwenna, especially in home gardens in this study. This tiny mite about $0.2 \mathrm{~mm}$ with translucent body damage to young leaves which 
curl downward and turn to coppery or purplish in color (Zhang 2003).

\section{Nematodes (Melodygyne spp,)}

Nematodes were another group of pests' attack to leafy vegetables especially Gotukola, Mukunuwenna and Nivithi in some locations (Plate 10). Their presence in Gotukola has already been reported (Wahundeniya et al. 2005). The damaged symptoms include narrowing and necrosis of leaves, growth retardation and when uprooted their root galls appears in the root system.

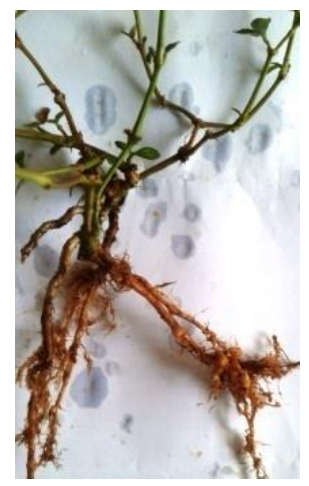

Plate 10: Nematode damage in Mukunuwanna

In addition, white hopper, white fly, black hopper, soft scales, aphids, mealy bugs, and leaf miner were the other minor pests observed in leafy vegetables during this study. However, Amaranthus stem borer, Hypolixus truncatulus (Coleoptera: Curculinoidae), which has been recently reported as a major pest of Thampala in Northern Province of Sri Lanka was not found in the sampled fields (Rajshkanna et al., 2017). This pest was earlier reported as a pest of $A$. spinosus Wijeratne (1999).

\section{CONCLUSIONS}

Pest problems with increasing trends badly affected the production and quality maintenance of leafy vegetable crops in Sri Lanka. The present investigations discovered a large number of pests damaging to both commercial and home garden grown leafy vegetables in Sri Lanka and some of them were new pests. Flea sap sucking bug, Halticus minitus and flea beetles, Chaetocnema spp. were identified as the most damaging pests of leafy vegetables and their damage, host range and biology were described. Flea weevil, Tachyyerges spp. was identified as a new occasional pest of Mukunuwenna and its morphology, biology and damage were described. Sweet potato flea beetle, Chaetocnema confinis was a new pest found causing serious damage to Kankun. Two leaf folders Psara basalis and beet webworm, Spoladea recurvalis were identified as pests of Mukunuwenna and Amaranths spp. A larval parasitoid of $S$. recurvalis was identified as a Bracon spp. and its parasitism exceed $30 \pm 5 \%$ in pesticide free cultivations indicating its potential as a biocontrol agent. The study confirms the presence of already recorded general pests namely, red spider mite, Tetranychus urticae, broad mite, Polyhagotarsonemus latus (Banks), nematodes, Melodygynye spp, leaf eating caterpillar, Spodoptera litura in leafy vegetable cultivations. An undescribed damage caused to the leaves of kankun was identified due to thrips. The study identified a coreid bug, C. trigonus as a pest of Amaranthus spp. White hopper, white fly, black hopper, soft scales, aphids, mealy bugs, and leaf miner were the other minor pests observed in leafy vegetables in this study.

\section{ACKNOWLEDGEMENTS}

Authors extend their sincere thanks to the director and officers of the division of Entomology, HORDI for providing the necessary facilities to carry out this study. The authors also wish to thank the Director, NAICC and the Deputy Director Agro technology park, Gannoruwa for their encouragement to make this publication a success.

\section{REFERENCES}

Amalin D.M. and Vasquez E.A. 1993. Jumping plant bug.

https://keys.lucidcentral.org/keys/sweetpotato/ key/Sweetpotato\%20Diagnotes/Media/Html/T heProblems/Pest-

suckingInsects/JumpingPlantBug/jumping\%20 plant\%20bug.htm

AtanuSeni 2018. Insect Pests of Amarathus and their management. International Journal of Environment, Agriculture and Biotechnology. 3 (3), 1100-1103.

Eyles A.C. 2005. Revision of New Zealand Orthotylinae (Insecta: Hemiptera:Miridae). New Zealand Journal of Zoology, 32:3, 181192.

https://doi.org/10.1080/03014223.2005.951841 1

Gupta R. and Singh D. 2013. Taxonomic notes on five species of the genus Cletus Stal (Heteroptera: Coreidae) from northern India with particular reference to their female genitalia. Journal of Entomology and Zoology Studies 1 (6): 44-51.

Hackston M. 2020. Keys to the British genera and species of subfamily Curculioninae (Curculionidae; Coleoptera). https://docs.google.com/viewer?a=v\&pid=sites \&srcid=ZGVmYXVsdGRvbWFpbnxtaWtlc21 uc2VjdGtleXMzfGd4OjExNTdmNWFmYjQy M2UxMjI

James B. Atcha-Ahowé C. Godonou I. Baimey H. Goergen H. Sikirou R. and Toko M. 2010. Integrated pest management in vegetable production: A guide for extension workers in West Africa. International Institute of Tropical 
Agriculture (IITA), Ibadan, Nigeria.: 50-53,6465.

Kumar R.G. Sharma and Ramamurthy V.V. 2008. Biosystematics of Psara basalis Walker. Indian Journal of Entomology, 70(4), 408-410.

Kafle S.KC.K. and K Lamjung. 2018. Species composition of leaf footed bugs (Coreidae: hemiptera) in hilly regions of Nepal. Campus, Institute of Agriculture and Animal Science. 35: $155-156$

Lakshani P.W.Y., Sumith J.A. Rajapaksha M.K. L.K Bambaradeniya R.R.M.I.. and Chathurange G.P.T. 2018. Pesticide residues in Alternanterases silis and Centella asatica grown in selected location in Sri Lanka. Annals of the Sri Lanka Department of Agriculture, 20: 15.

Marasinghe J.P. and Nishantha K.M.D.W.P. 2020. Flea beetle on leafy vegetables. Pest Management Decision Guide: Green and Yellow List, CABI Plantwise. file:///F:/20-031/Knowledge\%20Bank\%20Flea\%20beetle $\% 20$ on\%20leafy\%20vegetables.htm

Pierre Jolivet 2008. Sweetpotato Flea Beetle, Chaetocnemaconfinis (Coleoptera: Chrysomelidae: Alticinae)

https://www.semanticscholar.org/paper/Sweetp otato-Flea-Beetle\%2C-Chaetocnema-confinisJolivet-

Capinera/c2a142ed2381a08a4fb8315645e954a $4 \mathrm{e} 42 \mathrm{fd} 6 \mathrm{~d} 7$

Rajeshkanna S. N. Sivaranga and Mikunthan. 2017. Amaranthus stem borer Hypolixus truncatulus (Coleoptera: Curculinoidae). Annals of the Sri Lanka Department of Agriculture, 19: 258266.

Ruan, Yongying, Yang, Xingke, Konstantinov, Alexander S.. Prathapan, Kaniyarikkal, D., Zhang, Mengna, 2019.Rivision of theoriental Chaetocnema species (Coleoptera, Chrysomelidae, Galerucinae, Altcini). Zootaxa 4699 (1): 1-206. https://doi.org/10.11646/zootaxa.4699.1.1

Tsatsia H. and Jackson G. 1999. Sweetpotato flea hopper.

http://www.pestnet.org/fact_sheets/sweetpotat o_flea_hopper_026.htm

Tsatsia H. and Jackson G. 2017. Sweet potato flea beetle.

https://www.pestnet.org/fact_sheets/sweetpotat o_flea_beetle_096.htm

Wahundeniya K.B. Wahundeniya I. Ariyaratne I. and DE SilvaY.K.K. 2005. Annals of the Sri Lanka Department of Agriculture, 7:401.

Ward D.F. 2014. Bracon: Images and Factsheets. In: Braconidae of New Zealand. Landcare Research

Wijeratne P.M. 1999. Insects Feeding on Plants in Sri Lanka, Department of Agriculture. Pp. 171.

Zhang Z.Q. 2003. Mites of Green houses. CABI Publishing. Pp. 54-61 and 104-108. 